\title{
The effect of cognitive games on cognitive flexibility in children with mathematical disorders
}

\author{
Maryam Hasanvand, ${ }^{1}$ Ali Akbar Arjmandnia ${ }^{2}$ \\ 1-M. A of psychology \& Education of Exceptional Children, university of Tehran, Iran (Corresponding Author). \\ ORCID: 0000-0003-3749-7498 E-mail: fm.hasanvand@gmail.com \\ 2- Associate professor of psychology \& Exceptional Children, university of Tehran, Iran. ORCID: 0000-0001-8030- \\ 8416
}

Received: $12 / 01 / 2019$

\begin{abstract}
Introduction: Play therapy is effective in improving the cognitive problems of children with learning disabilities.

Aim: The objective of this study is to examine effectiveness of cognitive games (games based on executive functioning) on the cognitive flexibility of the students with dyscalculia.

Method: In this study which we have used the pre-test, post-test quasi-experimental design / plan with control group, 20 students with dyscalculia who were selected through purposive sampling, were randomly divided into control and experimental groups (each group $\mathrm{n}=10$ ). Wisconsin executive function test has used to assess cognitive flexibility performance. The data resulting from the study has analyzed by MANCOVA.
\end{abstract}

Results: The finding have shown that experimental group compared to control group have significant difference in the results of the test after participating in the intervention.

Conclusion: Cognitive games can improve the cognitive dysfunction of children with math disorders.

Keywords: Cognitive flexibility, Cognitive games, Dyscalculia

How to cite this article : Hasanvand M, Arjmandnia A A. The effect of cognitive games on cognitive flexibility in children with mathematical disorders. Shenakht Journal of Psychology and Psychiatry. 2019; 6 (2): 134-148 .URL :http://shenakht.muk.ac.ir/article-1-362-fa.pdf

Copyright $(\odot 2018$ the Author (s). Published by Kurdistan University of Medical Sciences. This is an open access article distributed under the terms of the Creative Commons Attribution-Non Commercial License 4.0 (CCBY-NC), where it is permissible to download, share, remix, transform, and buildup the work provided it is properly cited. The work cannot be used commercially without permission from the journal. 


\title{
مجله روانشناسى و روان يزشكى شناخت

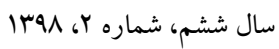 صفحات: IFA-IFA
}

\section{بررسى تأثير بازىهاى شناختى بر انعطاف شناختى كودكان داراى اختلال رياضى}

\author{
مريم حسن وند'، على اكبر ارجمندنيا' \\ ا.كارشناسى ارشد روانشناسى و آموزش كود كان استثنائى، دانشكاه تهران، ايران (مولف مسئول). ايميل: fm.hasanvand@gmail.com

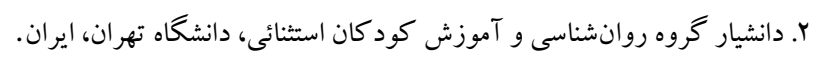

مقدمه: بازى درمانى در بهبود مشكلات شناختى كود كان داراى اختلالات يادگيرى اثربخش مىباشد.

هدف: هدف ئزوهش حاضر بررسى اثربخشى بازىهاى شناختى (بازىهاى مبتنى بر كاركردهاى اجرايى) بر انعطاف شناختى دانش آموزان داراى اختلال رياضى بود.

روش: در اين يُزوهش كه از طرح شبه آزمايشى بيش آزمون- بس آزمون با خروه كنترل استفاده شد، ·r نفر از دانش آموزان داراى

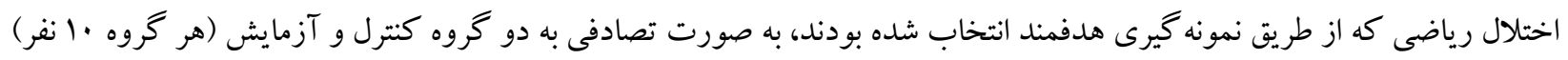

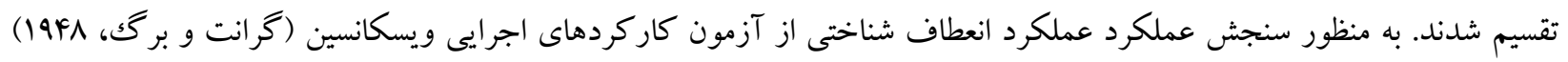

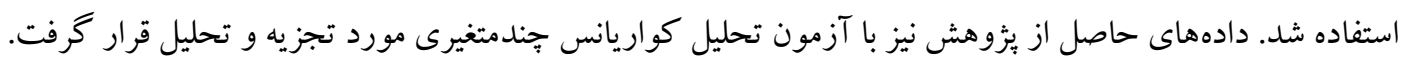
يافته ها: يافتها نشان داد كه گروه آزمايش در مقايسه با گروه كنترل، بِ از شركت در مداخله، در نتايج آزمون از نظر آمارى تفاوت معنادارى دارند.

نتيجه كيرى: بازى هاى شناختى منجر به بهبود عملكرد انغطاف شناختى كود كان داراى اختلال رياضى مىشود. كليدوازه ها: اختلال رياضى، انعطاف شناختى، بازىهاى شناختى 


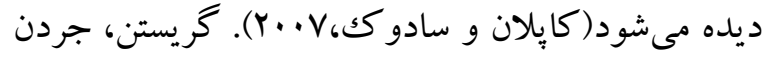
و فلوجو' (ه. ㄷ) در بررسى خود در ارتباط با كود كان داراى مشكلات رياضى به اين نتيجه دست يافتند كه مشكلات رياضى در سالهاى قبل از دبستان شروع مىشود و مشكل در شمارش، مقايسٔ كميتها، تشخيص

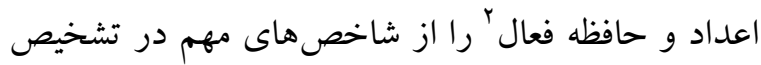

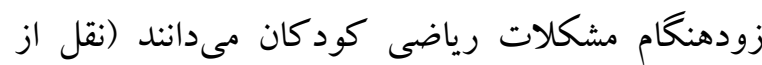

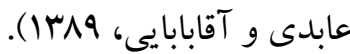
علل زيادى براى اختلال رياضيات عنوان شدهاست كه با با بال توجه به هر كدام از علتهاى ايجادكننده روشهاى

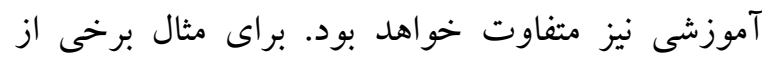

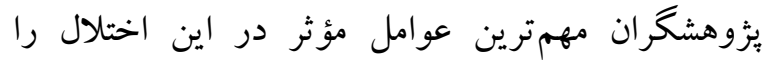

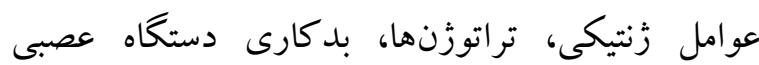
مركزى، اختلالهاى يردازش روانشناختى (هالاهان و

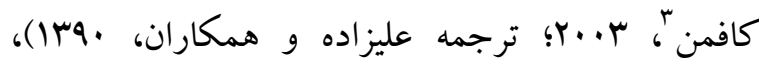
تدريس ناكافى، عملكرد بايين هوش غير كلامى، اختلال در تشخيص و درك بينايى، اختلال در تشخيص و درك شنوايى، اختلال در ادراك فضايى و فقدان آمادگى ذهنى

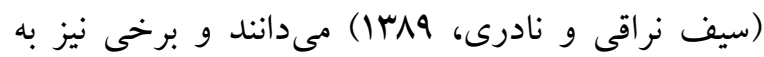
آسيبهاى عصبشناختى در ش شكل گيرى مشكلات

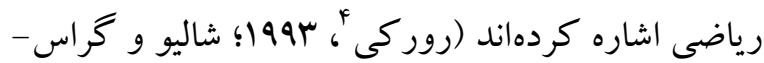

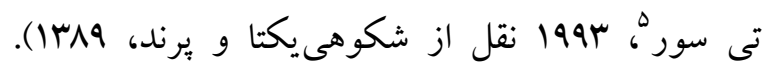
برخى يثزوهش ها ضعف در كاركردهاى اجرايى و حافظه فعال را علت اصلى در بيدايش مشكل در رياضيات

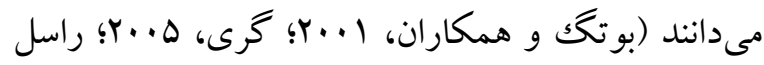

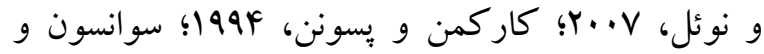

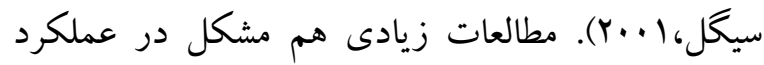

1. Gersten, Jordan \& Flojo

2 . Workinng Memory (WM)

${ }^{3}$. Hallahan \& Kauffman

4. Rourke

5. Shalev \& Gross Tsur

\section{مقدمه}

يكى از عمدهترين دلايل شكست تحصيلى در آلمان دانش آموزان، ناتوانىهاى يادگيرى است. اين ناتوانىها كروه نامتجانسى از اختلالها هستند كه مهمترين

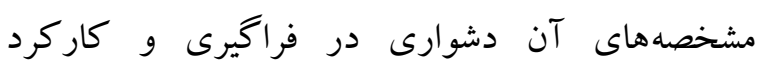
خواندن، نوشتن و محاسبات است كه روند تحولى داشته و از بيش از دبستان شروع و تا بزرگسالى ادامه بيدا

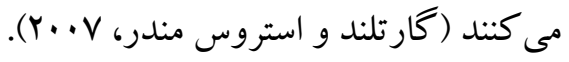
يكى از انواع اختلالات يادگيرى ، اختلال در رياضيات است كه در DSM-5، اختلال يادگيرى خاص با لـ اسبيسيفاير ديسكلكوليا نامخذارى شده است. اختلال رياضى به دامنه وسيعى از نارسايى توانايى رياضى در

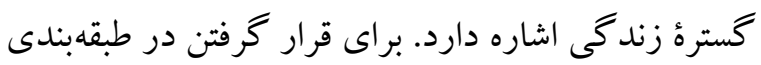

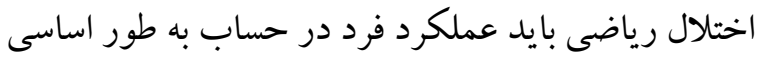
زير سن، توانايىهاى هوش و تحصيلى مورد انتظار باشد و همجنين اين اختلال بايد به طور جدى بر ويشرفت تحصيلى يا زندكى روزمره مشكل ايجاد كند. به علاوه اختلال نبايد به علت نقايص بينايى، شنوايى، جسمى،

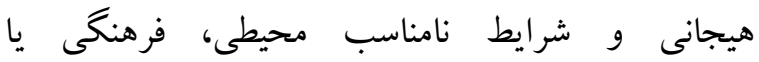

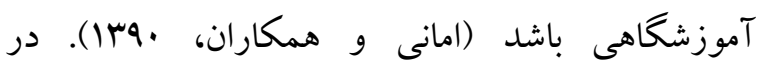
اختلالهاى رياضى نقايصى در جهار گرووه از مهارتها شناسايى شده است: () مهارت زبانى (مهارتهايى كه مربوط به درك اصطلاحات رياضى و تبديل مسائل نوشتارى به نمادهاى رياضى است)، Y) مهارتهاى ادراكى (توانايى شناسايى و دركك نمادها و مرتب كردن مجموعه اعداد)، ץ) مهارتهاى رياضى (جمع، تفريق، ضرب و تقسيم) و \&) مهارتهاى توجهى (كيى كردن صحيح اشكال و مشاهده درست مفاهيم عملياتى) اين اختلال اغلب همراه با خواندن و اختلال بيان نوشتارى 


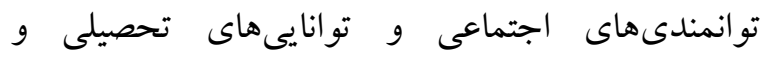

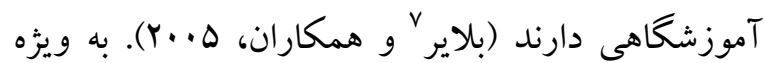
كه هر گونه نقص در رشد اين كار كردها، مىتواند موجب اختلال نقص توجه و بيشفعالى يا اختلال در برنامهريزى براى شروع و اتمام تكليف، به يادسبارى تكاليف، اختلال حافظه و اختلال يادكيرى شود. با توجه به اينكه كاركردهاى اجرايى يك فعاليت شناختى است، مىتوان

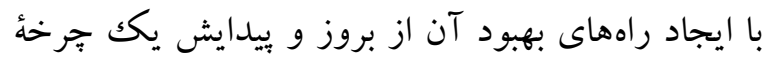

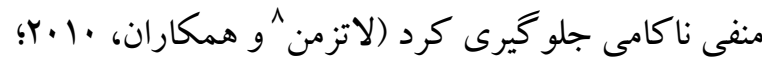

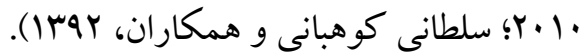
يكى از حوزههاى مرتبط با كاركردهاى جرايى، انعطافيذيرى شناختى است. انعطاف يذيرى شناختى " به توانايى انسان براى سازگار كردن راهكارهاى فرايند شناختى اطلاق مىشود كه به منظور مواجهه با شرايط

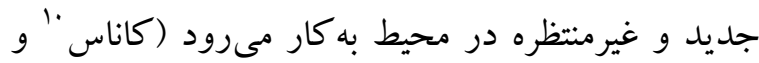

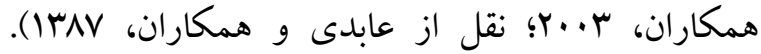
انعطاف يذيرى شناختى يكى از مؤلفهاى اصلى كاركرد

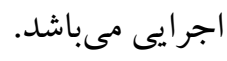

اختلال رياضى يكك اختلال بيجيده است و بر مبناى توانايىهاى شناختى مختلف شكل مى گيرد و نسبت به اختلال خواندن توجه بسيار كمترى به آن شدهاست، با اين وجود، شمار رو به رشد دانشآموزان با اختلال رياضى به علايق تخصصى در اين زمينه نيرو بخشيده

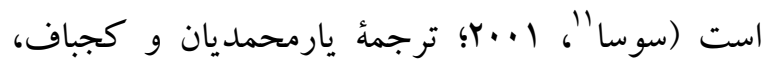
MM IMM بهور كلى، درك دانش و مهارتهاى رياضى براى تمام دانش آموزان به ويزه دانش آموزان مبتلا به

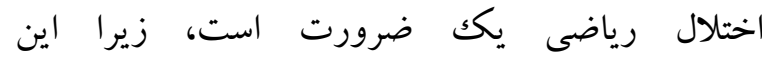

${ }^{7}$. Blair etal

${ }^{8}$. Latzman etal

${ }^{9}$. Cognitive flexibility

${ }^{10}$. Cañas etal

${ }^{11}$. Souse
لوب پيس سرى در بروز مشكلات رياضى را عنوان

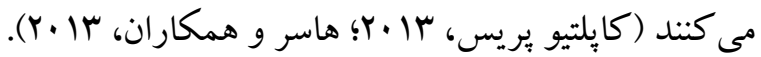
با اين وجود بيزوهشهاى جديد به نقش مهارتهاى فراشناختى و از اين ميان نقش آموزش كاركردهاى اجرايى بر بهبود اختلال يادگيرى تأكيد دارند(وندراسلويز

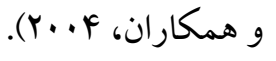

كاركردهاى اجرايى به عنوان مجموعهاى از فرايندهاى فرضى تصور مىشود كه افراد را قادر مىسازد آكاهانه رفتار و افكار خود رادر جهت اهداف آينده كنترل كنند. اين فرايند معمولاً شامل مؤلفههاى بازدارى، حافظه فعال، انعطافيذيرى ذهنى، برنامهريزى، سازماندهى روانى و اكتساب مفهوم مىشود، همجنين كاركردهاى اجرايى را مى توان به عنوان يك رهبر اركستر توصيف كرد كه رفتارهاى ديخر را هدايت و كنترل مىنمايد (برون'، ه..r؛ نقل از على يور و مهدوى، سوس|). در تحقيقى كه روى مشكلات كاركردهاى اجر ايى دانش آموزان صورت كرفت، نشان داد كه دانشآموزان داراى اختلال رياضيات در تمام كاركردهاى اجرايى مشكل دارند

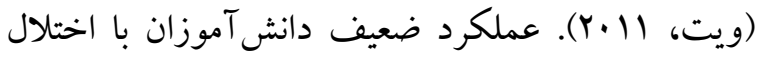
ياد گيرى در آزمونهاى مربوط به كاركردهاى اجرايى و حافظه فعال در تحقيقات زيادى تأييد شدهاست

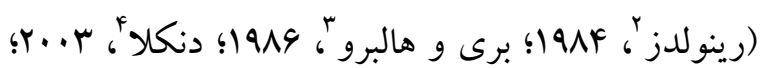

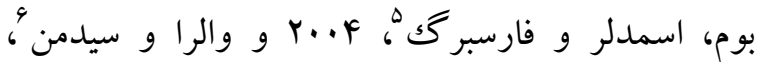

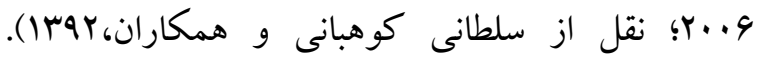
همجينين تحقيقات نشان دادهاند كه آموزش و رشد

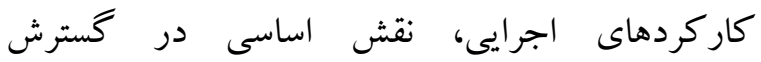

\footnotetext{
. Brown

${ }^{2}$. Reynolds \& Chowdbury

3. Holborow \& Berry

4. Denckla

5. Bohm, Smedler \& Forssberg

6. Valera E, \& Seidman
} 
كه در دامنهُ سنى V تا • ا سال رشد كاركردهاى اجرايى سرعت مى يابد و در بايان بزر گسالى به بالاترين حد خود

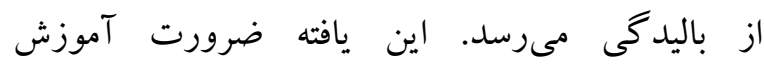
كاركردهاى اجرايى از ابتداى كودكى تا بزرگسالى را يادآور مىشود (براردى و همكاران، ه9919؛ نقل از

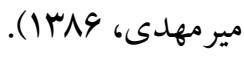

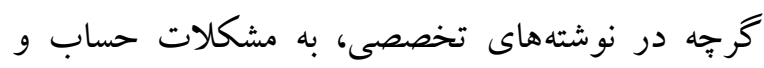

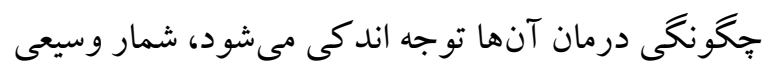
از كودكان و نوجوانان مدارس ما، همجِنان در درس حساب با مشكل روبرو هستند؛ لذا موضوعى كه يس از تشخيص اين نوع ناتوانى مهم است به كار بستن اقدامات درمانى به موقع و مناسب جهت بهبود مشكلات اين دانش آموزان و جلو گيرى از آسيبهاى بعدى است. امروزه از روشهاى بسيارى در كمكك به كود كان داراى اختلالات يادكيرى و ارتقاء توانايىهاى آنها بهره برده مىشود كه از جملة اين موارد مىتوان به درمانهاى شناختى اشاره كرد. در خصوص ويزّى هاى شناختى افراد مبتلا به اختلالات يادگيرى، بررسىهاى صورت كرفته، تعدادى از فرايندهاى شناختى ويزه را مشخص ساختهاند كه كودكان مذكور را از همسالان بهنجارشان متمايز مى كند كه بيشتر اين بثروهشها بر روى فرايندهاى حافظه، توجه، فراشناخت و اسناد متمركز بودهاند.

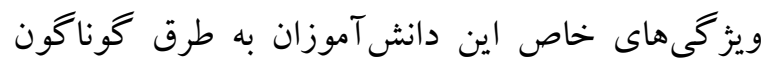
بيان مىشوند: فعال نبودن ياد گيرندگان، نابسندگى حلى حل مسئله، درماندكى آموخته شده و ناكار آمدى در استفاده از راهبردهاى شناختى (راينيكهو و همكاران، ترجمه علاقبندراد و فرهى، ·^ش|). بر همين اساس علاقه به

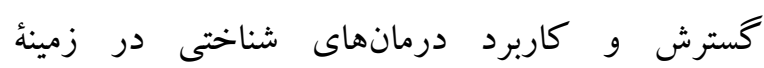

${ }^{2}$. Reineck etal
دانش آموزان بايد بتوانند با تسلط يافتن بر مفاهيم، اصولى را كه فراكرفتهاند در موقعيتهاى روزانه به كار ببندند

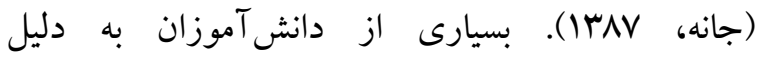
شكستهاى مكرر تحصيلى دجار ناكامى مىشوند و تركى تحصيل مى كنند، همجينين در صورتى كه مشكلات آنها بهموقع تشخيص داده نشود و برنامههاى مداخلهاى

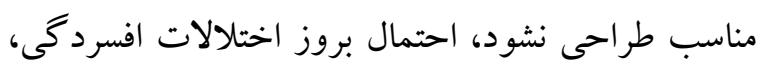
اضطرابى و بزهكارى در اين كودكان افزايش مىيابد

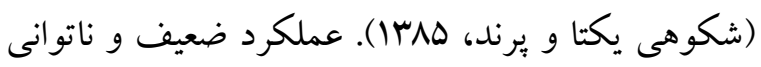
در رياضيات در دنياى اقتصادى امروز اثرات زيادى در سلامت روانى و جسمى افراد جامعه دارد (كدوش و همكاران، سا •YY). مايسنى، مكك ناوتون و رول' (1999) به بررسى يُزوهشهاى انجامشده در زمينهُ اختلالات درس رياضى برداختند و تنها شش مطالعه در مورد عملكرد دانش آموزان با ناتوانى ياد گيرى در جبر يافتند و اغلب يزوهشهايى كه در حيطهُ ناتوانىهاى ياد گيرى

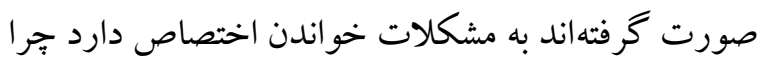
كه فرض بر اين است كه اختلالات خواندن بر ساير ناتوانىهاى يادگيرى و مهارتهاى زبانى تأثير دارد

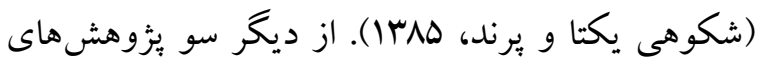
اخير مبين ارتباط بين حافظه و مشكلات يادگيرى و به ويزه مشكلات رياضى هستند (سوانسون و همكاران،

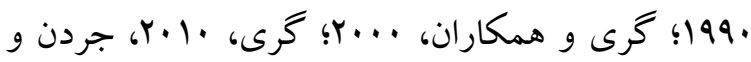

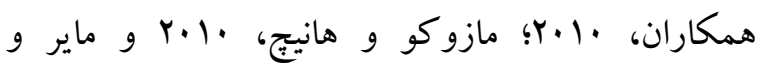

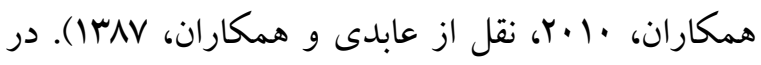
يكك مطالعه توسط هايدست و بريهام (199r) شواهدى از كسترش و اوج باليدگى كاركردهاى اجرايى از ابتداى كودكى تا بزر گسالى شواهدى به دست آمد و نشان داد

\footnotetext{
1. Maccini, McNaghton \& Ruhl
} 
عبارتى بازىدرمانى فرآيندى تخصصى است كه در آن،

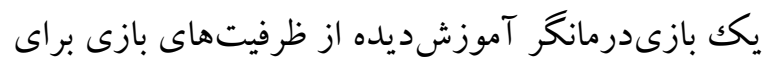
كمكك به مراجعين و بهبود بخشيدن به عملكردهاى ايشان جهت بهبود اختلالات و همجنين دستيابى به رشد و

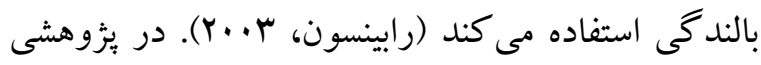

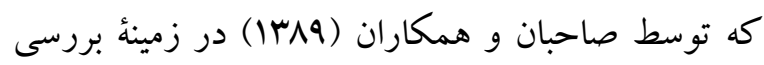
اثر كوتاهدت آموزش كاركردهاى اجرايى (بازىهاى

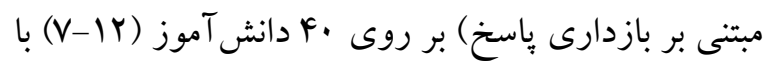

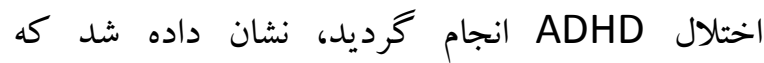
بازىهاى مبتنى بر بازدارى ياسخ موجب كاهش نشانهاى

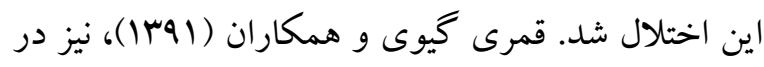
يخوهشى نشان دادند كه بازى نرمافزارى بيشبرد شناختى إنى بر بهبود بازدارى يّاسخ و حافظهُ فعال كودكان دجار نارساخوانى و نقص توجه- بيشفعالى تأثير دارد. مور (Y...) يُووهشهاى خود نشان دادند كه خود كنترلى، برنامهريزى و بازدارى باسخ و ديخر عملكردهاى اجرايى در طول

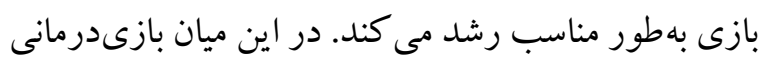

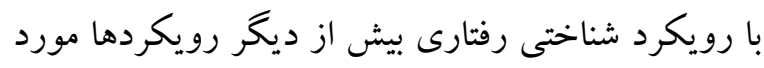
استفادهُ درمانگران قرار گرفته است. هر جند بازىدرمانى

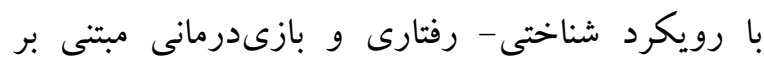
كاركردهاى شناختى در بعد شناختى مشترككاند، ليكن بازىدرمانى شناختى - رفتارى بر اصلاح تعبير و تفسيرهاى

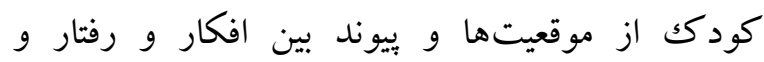

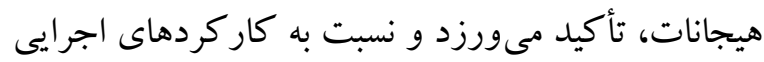
جهت گيرى خاصى ندارد، در حالى كه در بازىدرمانى مبتنى بر كار كردهاى شناختى، هدف اصلى مهارتافزايى فرد در كار كردهاى اجرايى است و تكاليف و فعاليتهاى بازى گونهُ آن بر توانمندسازى فرد در به كارگيرى مؤثر
اختلالهاى ياد گيرى در سالهاى اخير افزايش يافته است. اگرجهه سالهاى متمادى درمانهاى شناختى براى انواع مشكلات بالينى بزر گسالان و كود كان مورد استفاده قرار

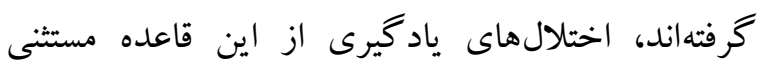

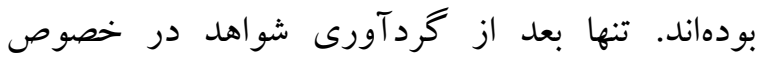
ويز گى هاى شناختى مربوط به اختلالهاى يادگيرى بود كه اين قلمرو، رويكرد شناختى را انتخاب كرد. در واقع درمانهاى شناختى بر اين باور مبتنى هستند كه

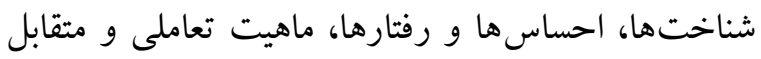
دارند؛ بدين سبب رويكردهاى شناختى با نيازهاى دانش آموزان دجار اختلالهاى ياد گيرى كه ويز گیىهايى مانند درماندگى آموخته شده، نقص در خودنظمبخشى، آكًاهى فراشناختى محدود و مشكلاتى در توجه و حافظه را نشان مىدهند، ساز گارى زيادى دارند (هريس، 1911). يثزوهشهايى كه نشانكر نقايص شناختى در بين افراد مبتلا به اختلالهاى يادگيرى هستند، مبناى محكمى را براى ايجاد و گسترش درمانهاى شناختى فراهم ساختهاند؛ زيرا اين رويكردها جندجانبه هستند و دستهُ وسيعى از راهبردها و فنون مناسب براى دانش آموزان مبتلا را با هم تلفيق مى كنند و به فعال ساختن دانش آموزان و سيردن كنترل و مسئوليت شخصى به آنها در ارائه راه حل مسائل تأكيد دارند (فينج و همكاران، سوإ؛ نقل از اميرى و

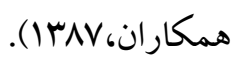
درمانهاى شناختى مىتواند در غالب بازى به كودكان ارائه شود. بازىدرمانى يكى از روشهاى مؤثر در درمان مشكلات رفتارى و روانى كودكان است. بر اساس تعاريف رايج، بازىدرمانى نوعى مداخلهُ درمانى است كه

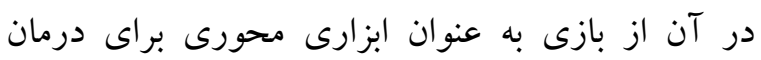

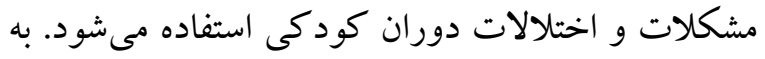


يثزوهش به صورت شبه آزمايشى است كه از طرح بيشكاركردهاى اجرايى متمركز است (اصغرى نكاح، آزمون - بِ آزمون استفاده شده است. ملاككهاى ورود rrma

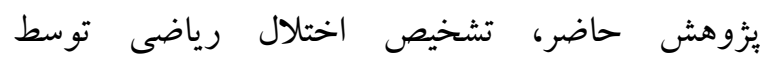

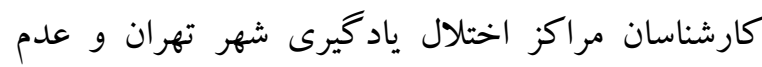
همبودى با اختلال نقص توجه و بيشفالى و عدم دريافت درمانهاى ديخر در طول مدت اجراى بثزوهش و پايه تحصيلى دوم تا جهارم ابتدايى بود. سبس برنامعٔ

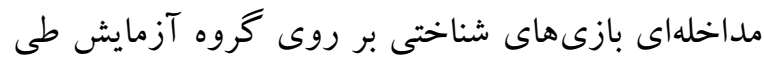
r r جلسة .9 دقيقهاى به مدت يكك ماه و نيم (شش هفته) اجرا شد. دادههاى جمع آورى شده با استفاده از بسته آمارى آجري و و به كاركيرى مدل كوواريانس تكك متغيرى (ANCOVA) و جند متغيرى (MANCOVA)

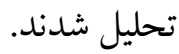
خلاصه جلسات درمانى در جدول شماره ا ذكر شده

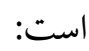

\begin{abstract}
با توجه به ضعف افراد داراى اختلال ياد گيرى رياضى در

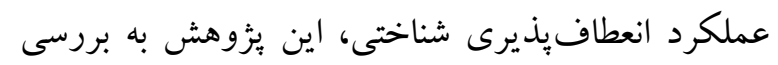
اثربخشى بازىهاى شناختى بر عملكرد انعطافيذيرى

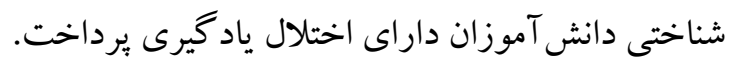
جامعهُ آمارى يُزوهش حاضر در بر گيرندة تمام افرادى است كه به مراكز اختلال ياد گيرى شهر تهران مراجعه كردهاند و تشخيص اختلال يادگيرى رياضى گرفتهاند. نمونهُ ئزوهش حاضر شامل ·r نفر از اين جامعه بود كه در پيايههاى دوم، سوم و جهارم دورهُ ابتدايى بودند. از تعداد فوق به صورت تصادفى ·ل نفر به گروه آزمايش و

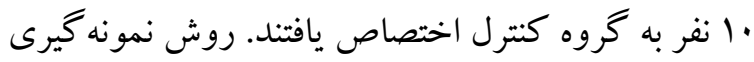
در اين بزوهش به شيوه نمونه كيرى هدفمند بود. اين

\section{جدول ا خلاصه جلسات درمانى}

\begin{tabular}{|c|c|}
\hline 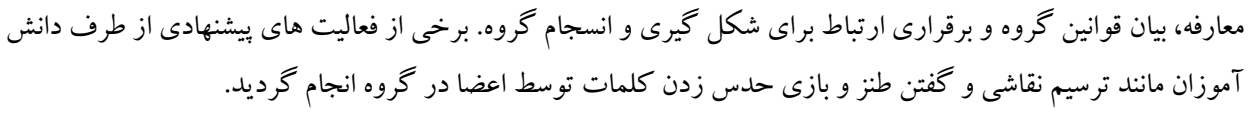 & جلسه اول \\
\hline 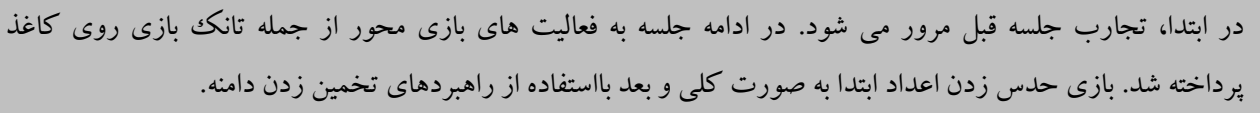 & جلسه دوم \\
\hline بازى با كارت كلمات، بازى جابهجايى اشيا. & جلسه سوم \\
\hline شمارش يُكانى مستقيم و معكوس. & 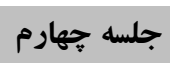 \\
\hline بازى با كارت اعداد، ييدا كردن اعداد قبل و بعد كارت هدف. & 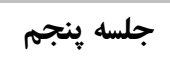 \\
\hline باد كنكك اعداد، جور كردن كارتهاى حرف و عدد، هب بازى. & 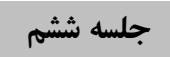 \\
\hline جستجو در جدول اعداد و حروف. & جلسه هفتم \\
\hline ييدا كردن اعداد از روى جدول رمزى. & 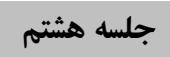 \\
\hline منج بازى با دو تاس و سه تاس. & جلسه نهم \\
\hline عدد نو يسى با خند رنگك، نوشتن بدون نقطه. & جلسه دهم \\
\hline
\end{tabular}




\section{جلسه دوازدهم تر كيبى از فعاليت هاى جلسات گذشته با انتخاب مشار كت كنند گان.}

اصل بعدى تعداد مىباشد و بعد سه اصل به ترتيب تكرار مىشوند. آزمون زمانى متوقف مىشود كه آزمودنى بتواند 9 طبقه را به صورت دستهبندى نمايد. در محاسبه جند نمره از اين آزمون به دست مى آيد كه دوتاى آن از همه مهمتر است. نمره خطاى درجامانكى: وقتى انجام مىشود كه على رغم تغيير اصل بر اساس اصل قبلى به

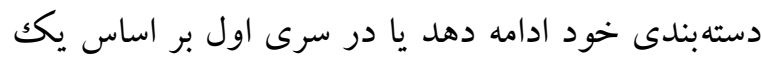
اصل غلط به دستهبندى خود مبادرت ورزد و حتى در

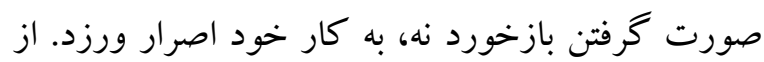
آنجايى كه ياسخ همهُ آزمودنىها يكسان نيست مىتوان از نسبت ياسخهاى درجامانده استفاده كرد. نمرهُ تعداد طبقات به دست آمده: طبقات به تعداد دستهبندىهاى صحيح اطلاق مىشود و از · تا •9 در نوسان است. اكسرود و همكاران اظهار مى كنند كه بايايى بين ارزيابان رضايتبخش بوده است. يايايى بين ارزيابان در اين آزمون در حد عالى و بالاى به/. •زّارش شده است. تعداد ياسخهاى صحيح: يعنى تعداد كارتهاى صحيحى 4. كه دستهبندى كرده است (حداكثر .9 نمره براى

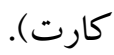

يافته ها در جدول Y r Fا F يافتهاى توصيفى جمعيتشناختى براى دو كروه آزمايش و كنترل به تفكيك ارائه شده است.
ابزار آزمودنىها قبل و بعد از مداخله با ابزار زير مورد ارزيابى

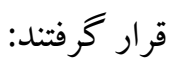
آزمون دستهبندى كارت هاى ويسكانسين: اين آزمون ابتدا توسط گرانت و برگك در سال 1941 ساخته شد. در مطالعهُ رفتار انتزاعى و انعطافيذيرى شناختى از اين

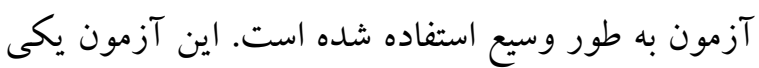
از شاخص هاى اصلى فعاليت قطعهُ بيشانى است و امروزه به عنوان ارزيابى كنندهُ ميزان انتقال ياسخ كه يكى از مؤلفهاى كاركردهاى اجرايى است به كار مىرود

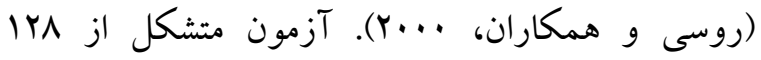
كارت غير مشابه و با شكلهاى متفاوت (مثلث، ستاره، صليب و دايره) و با رنگَكاى مختلف است. براى اجراى آزمون ابتدا F كارت الكَ در مقابل آزمودنى قرار داده مىشود. آزمونكر ابتدا رنگك را مبناى دستهبندى قرار

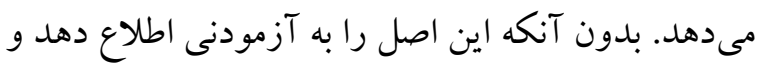

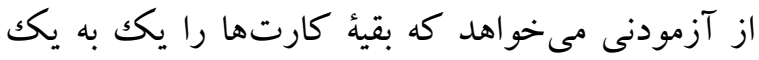
زير كارت قرار دهد. بعد از هر كوشش به آزمودنى كفته مىشود كه تلاشش درست بوده يا خير. اخر آزمودنى بتواند به صورت ييايى ·ل دستهبندى درست انجام دهد اصل دستهبندى تغيير مى كند و اين اصل دستهبندى، شكل خواهد بود. تغير اصل فقط با تغيير دادن الكوى

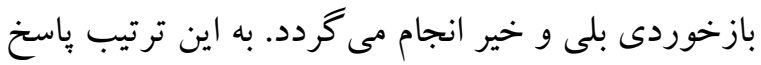
صحيح قبلى، در اصل جديد، پاسخ غلط قلمداد مى گردد. 


\begin{tabular}{|c|c|c|c|c|c|c|c|}
\hline كمينه & بيشينه & خطاى استاندارد & استاندارد افر اف & ميانكين & تعداد & كروه & ويزگى \\
\hline$\wedge$ & 1. & $\cdot / Y F$ & $\cdot / \mathrm{V} \Lambda$ & $\Lambda / \Lambda$ & 1. & آزمايش & سن \\
\hline$\wedge$ & 1. & . & $\cdot / M r$ & $9 / 1$ & 1. & كنترل & \\
\hline
\end{tabular}

جدول r بايةٌ تحصيلى كروه نمونه به تفكيك كروه كنترل و آزمايش

\begin{tabular}{|c|c|c|c|c|c|}
\hline & Fروه & & كروه آزمايش & طبقات & متغير \\
\hline درصد & فراوانى & درصد & فراوانى & & \\
\hline r. & r & f. & $f$ & دوم & هايةٌ \\
\hline$\Delta$. & $\Delta$ & f. & f & سوم & يلى \\
\hline$r$. & $r$ & $r$. & $r$ & جهارم & \\
\hline
\end{tabular}

جدول ب جنسيت تروه نمونه به تفكيك تروه كنترل و آزمايش

\begin{tabular}{|c|c|c|c|c|c|}
\hline \multicolumn{2}{|c|}{ كروه كنترل } & \multicolumn{2}{|c|}{ كروه آزمايش } & طبقات & متغير \\
\hline درصد & فراوانى & درصد & فراوانى & & \\
\hline 9. & 9 & v. & V & دختر & جنسيت \\
\hline f. & f & r. & $r$ & پֶ, & \\
\hline
\end{tabular}

به منظور تجزيه و تحليل دادهها از روشهاى آمار همسانى گروه آزمايش و كنترل) و كواريانس براى توصيفى مثل ميانخين، واريانس و انحراف استاندارد و بررسى تفاوت نمرات بيش آزمون- يّس آزمون و تفاوت

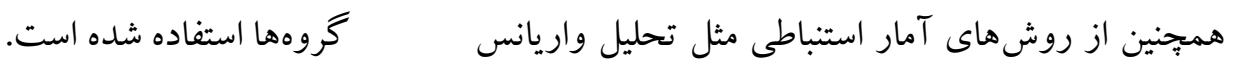
جندمتغيرى، آزمون برابرى لوين (به منظور برابرى و

\begin{tabular}{|c|c|c|c|c|c|c|c|}
\hline بيشينه & كمينه & خطاى استاندارد & استاندارد افحراف & انحراف & مرحله & كروه & خرده \\
\hline ir & 1 & $1 / r 1$ & $r / A F$ & $9 / 1$ & بيش آزمون & آزمايش & \multirow{4}{*}{ خرجاماند } \\
\hline 11 & $\cdot$ & $1 / \cdot r$ & $r / r r$ & $V / F$ & بֶ آزمون & & \\
\hline 11 & r & $1 / A V$ & $\Delta / 9 Y$ & $11 / 1$ & بيش آزمون & كنترل & \\
\hline 19 & r & $1 / 1 M$ & D/Q9 & $\mid r / r$ & بֶ آزمون & & \\
\hline$r$ & . & $\cdot|r|$ &.$/ 99$ & $1 / 9$ & يِيش آزمون & آزمايش & \multirow{5}{*}{ طعداد } \\
\hline$\Delta$ & r & r & $1 / .0$ & $r / r$ & بֶس آزمون & & \\
\hline$\Delta$ & . & $\cdot / 4 \Lambda$ & $1 / \Delta r$ & $1 / 9$ & بيش آزمون & كنترل & \\
\hline$\Delta$ & $\cdot$ & D A & $1 / r r$ & $1 / V$ & بِ آزمون & & \\
\hline rv & 19 & $1 / 99$ & $9 / \pi 1$ & TV/A & يِيش آزمون & آزمايش & \\
\hline
\end{tabular}




\begin{tabular}{|c|c|c|c|c|c|c|}
\hline pr & ro & $1 / \wedge \Delta$ & $\Delta / \wedge \Delta$ & $M F / F$ & يس آزمون & تعداد \\
\hline (i) & rr & $1 / 94$ & $\Delta / Y F$ & rr & يويش آزمون & پِاسخهاى \\
\hline Fr & rF & 1/A9 & $0 / \cdot 9$ & rr/A & يّ آزمون & صحيح \\
\hline
\end{tabular}

نمرات در بيش آزمون و بس آزمون بيانگر عدم تفاوت و تغيير در گرووه كنترل مىباشد. ابتدا فرض نرمال بودن در مورد آزمون كاركردهاى اجرايى ويسكانسين مورد بررسى قرار كرفت.
همانطور كه در جدول ه نشان داده شده است، نمرات افراد در گروه آزمايش در بيش آزمون و يس آزمون نشان

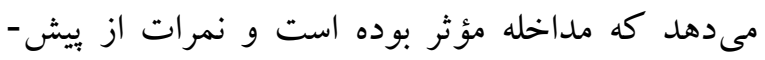
آزمون تا بس آزمون تغيير داشته و افزايش يافته است. در بررسى نمرات گروه كنترل نشان داده مىشود ميانگين

\begin{tabular}{|c|c|c|c|c|}
\hline \multicolumn{5}{|c|}{ كار كردهاى اجرايى ويسكانسين به تفكيك خرده آزمونها } \\
\hline سطح معنادارى & درجه آزادى & آماره & مقياسها & كروه \\
\hline $.1 .9 \mathrm{~V}$ & 1. & - / $\Delta \Delta \Delta$ & خطاى درجاماندگى & \\
\hline . / lar & 1. & $\cdot / M 9$ & تعداد طبقات & 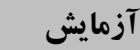 \\
\hline.$/ 911$ & 1. &.$/ 901$ & تعداد بِاسخهاى درست & \\
\hline$\cdot / \mathrm{AV}$ & 1. & $\cdot / \wedge 94$ & خطاى درجاماندگى & \\
\hline$\cdot 1 \cdot \mathrm{vr}$ & 1. & $\cdot / A \Delta V$ & تعداد طبقات & 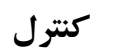 \\
\hline -/V99 & 1. &.$/ 9 \Delta \wedge$ & تعداد بِاسخهاى درست & \\
\hline
\end{tabular}

معنادارى كمتر از هـ/ • نبوده و اين نكته به اين معنا است كه توزيع نمرات در اين متغير نرمال است در نتيجه اولين بيشفرض استفاده از تحليل كواريانس برقرار بوده و استفاده از تحليل كواريانس بلامانع است.
همانطور كه درجدول 4 مشاهده مىشود نتايج آزمون شاييرو-ويلك نشاندهنده اين موضوع است كه هر دو كروه كنترل و آزمايش در آزمون كاركردهاى اجرايى

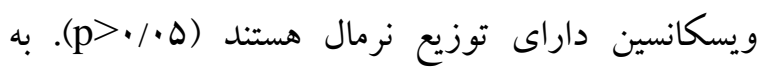
عبارتى در آزمون كاركردهاى اجرايى ويسكانسين سطح

جدول \ آزمون لوين جهت بررسى فرض همسانى واريانس خطاى نمرههاى وابسته در آزمون

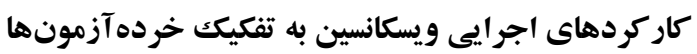

\begin{tabular}{|c|c|c|c|c|}
\hline سطح معنادارى & درجه آزادى خطا & درجه آزادى & آزمون لوين & مقياسها \\
\hline$\cdot / 199$ & 11 & 1 & $1 / \lambda \cdot \Delta$ & خطاى درجاماندكى \\
\hline$\cdot / \Delta \cdot 1$ & 11 & 1 & $\cdot / F \Delta V$ & تعداد طبقات \\
\hline$\cdot / 0 . r$ & 11 & 1 & - Far & تعداد ياسخ هاى صحيح \\
\hline
\end{tabular}


مشاهده شده معنادار نشده است (p>//. (p) در نتيجه مفروضةٌ برابرى واريانس خطاى آزمون كاركردهاى اجرايى ويسكانسين برقرار مىباشد و استفاده از تحليل

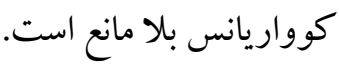

بيشفرض دوم در استفاده از آزمون تحليل كواريانس، فرض همسانى واريانسها است. از اين رو از آزمون لوين به منظور بررسى فرض همسانى واريانس خطاى نمرههاى وابسته در آزمون كار كردهاى اجرايى ويسكانسين استفاده شد. همانطور كه در جدول V مشاهده مىشود نسبت

\begin{tabular}{|c|c|c|c|c|}
\hline سطح معنادارى & آزمون لوين & ميانكين مجذورات & درجه آزادى & مقياسها \\
\hline$\cdot /$ rA. & $\cdot /$ ATV & $\cdot / 9 \vee V^{4}$ & $1 / \lambda \cdot \Delta$ & خطاى درجاماند حى \\
\hline $.1 .9 \mathrm{~V}$ & $r / 991$ & $r / 490$ & $\cdot / F \Delta V$ & تعداد طبقات تعدادياسخهاى \\
\hline$\cdot / r \cdot 1$ & $1 / V \Delta G$ & $1 \% / 9 r$. & . Far & صحيح \\
\hline
\end{tabular}

دادههاى حاصل از يُزوهش حاضر در زمينه آزمون كار كردهاى اجرايى، تحليل كواريانس جند متغيرى مورد

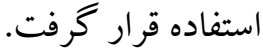
قبل از انجام اين تحليل برقرارى بيشفرض همسانى ماتريسهاى كواريانس به وسيلة آزمون ام باكس نيز مورد بررسى قرار كرفت كه نتايج آن نيز حاكى از 4 برقرارى اين بيشفرض است ( F= (1/9)

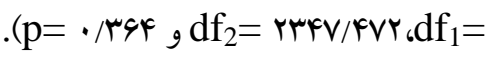

همانطور كه در جدول ^ مشاهده مىشود سطح معنادارى در محاسبة همكنى شيب خط رگرسيون براى آزمون كاركردهاى اجرايى ويسكانسين معنادار نيست به اين معنا كه تعامل بين شرايط آزمايشى و متغير همبراش معنادار

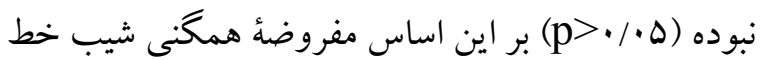
ركرسيون نيز برقرار است. با توجه به برقرارى دو مفروضه از مفروضههاى فوق (شيب خط ركرسيون و نرمال بودن توزيع) براى تحليل

جدول 9 نتايج كلى آزمونهاى جندمتغيرى آزمون كار كردهاى اجرايى ويسكانسين

\begin{tabular}{|c|c|c|c|c|c|}
\hline معنادارى سطح & كروهها به درون تغييرات بين & درجه آزادى & درجه آزادى & مقدار & نوع آزمون \\
\hline.$/ \cdots 1$ & $|r / A|$ & ir & $r$ & - /VFV & اثر پيلايى \\
\hline.$/ . .1$ & $|r / A|$ & ir & $r$ & . Tor & لامبداى ويلكز \\
\hline$\% \cdot \cdot 1$ & $|r / A|$ & ir & $r$ & $r / 9 \Delta V$ & اثر هاتلينك \\
\hline.$/ . .1$ & $|r / A|$ & ir & $r$ & $r / Q \Delta V$ & بزر كترين ريشه روى \\
\hline
\end{tabular}

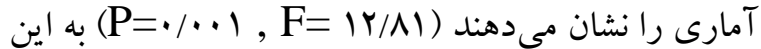
معنى كه آزمون كاركردهاى اجرايى در بيش آزمون و يس آزمون به صورت معنادارى متفاوت شده است.
همانطور كه در جدول 9 نشان داده شده است هر جهار آزمون جند متغيرى (لامبداى ويلكز، اثر هاتلينگك، بزركترين ريشه اختصاصى روى و اثر بيلايى) معنادارى 


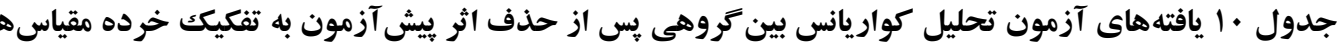

\begin{tabular}{|c|c|c|c|c|c|c|}
\hline توان آزمون & مجذور ايتاى سهمى & معنادارى سطح & كروهها به درون تخييرات بين & درجات & نوع سوم & مقياسها \\
\hline$\cdot / 9 M$ & $\cdot 109 V$ & $\cdot 1 \cdots 1$ & $r \cdot / r \Delta V$ & 1 & M/AVA & درجاماند خطىى \\
\hline$\cdot / 9 \cdot F$ & - / fFa & $\cdot / \cdot r$ & IY/YYV & 1 & $\Lambda / \cdot 1 f$ & تعداد طبقات \\
\hline$\cdot|M|$ & $\cdot / k r$. & $\cdot / \cdot F$ & $11 /$ rar & 1 & $W / 199$ & تعداد ياسخهاى \\
\hline
\end{tabular}

كمكك كرد تا بيشتر مشاركت داشته و خودباورى بيشترى داشته باشند و در برخورد با تكاليف جديد راهكارهاى بيشترى ارائه دهند. همجينين در خلال اين بازىها،

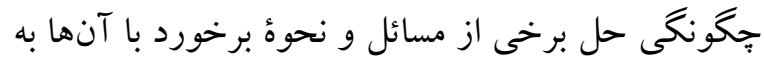
كودكان آموزش داده شد كه تجربيات حاصل از اين بازىها موجب خوديرورى كودكك شده و توانايى استفاده از اين اطلاعات و سازمان دادن به آنها را به كودكك داده تا بتواند در موقعيتهاى ديخر از آنها |ستفاده كند. براى مثال در بازى حدس زدن اعداد، كودكى يكك سرى راهبردهاى شناختى را فرا مى گيرد، و مى آموزد كه مسائل مىتوانند به كونهاى ديخر نيز حل شوند. در اين بازى درمانگر به كودك مى گويد: من به يكك عددى فكر مى كنم كه در ذهن من است، تو بكو آن عدد كدام است؟ معمولاً كود كان در يُاسخ به اين سؤال بدون آن كه سؤالى را مطرح كنند اعدادى را كه به ذهنشان مىرسد بيان مى كنند اما در خلال اين بازى آموزش مىبينند كه از راهبرد تخمين دامنه استفاده كنند تابه باسخ صحيح دست يابند. ضعف انعطاف يذيرى يا درجاماندگى با توانايى رياضيات

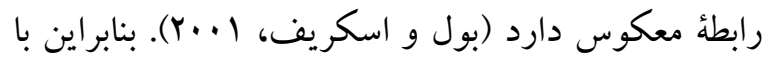

همانطور كه در جدول ·1 مشاهده مىشود به منظور بررسى ميزان اثربخشى برنامهُ مداخله در عملكرد انعطاف يذيرى شناختى دانش آموزان داراى اختلال رياضى تحليل كواريانس جندمتغيرى مورد استفاده قرار كرفته است. نتايج حاصل از اين تحليل نشان مىدهد كه كروه آزمايش در مقايسه با كروه كنترل، يس از شر كت در مداخله، در نتايج آزمون از نظر آمارى تفاوت معنادارى داشته است. انخيزهُ ييشرفت و ميل به برنده شدن در بازى، دانش آموز منفعل را به تكايو و انديشيدن وادار مى كند. ايجاد محيطى امن و مثبت براى كودكان كه در آن بتوانند توانايىهاى خود را به عرصهُ ظهور برسانند، فارغ از آن كه آنها را با يكديكر مقايسه كرده و احساس ضعف را در آنها ايجاد كنيم مى تواند موجبات شكوفايى توانمندىهاى كود كان را فراهم كند. در روند اين درمان، سعى درمانكر بر اين بود كه دانش آموزان را مرحله به مرحله مورد تشويق قرار دهد تا آنها بتوانند تصوير جديدى از خود در ذهنشان بسازند و اعتماد به نفس از دست رفتهُ خود را مجدداً به دست آورند كه اين موضوع به نوبئ خود به دانش آموزان 
نتيجه كيرى

بنابراين برمبناى يافتهاى حاصل حاصل از اين يزوهش كه نشان داد بين دو گروه آزمايش و كنترل در بهببود عملكرد برد انعطاف يذيرى شناختى تفاوت معنادارى وجود دارد مى توان جنين نتيجه گرفت كه مداخلهُ بازىهاى شناختى در

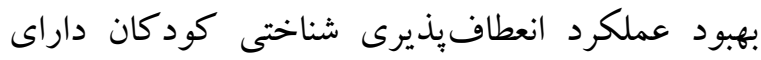

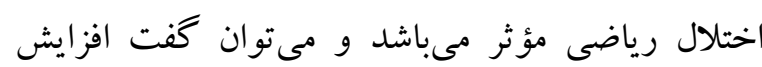
عملكرد انطافيذيرى شناختى در درمان ناتوانىهاى يادگيرى به ويزه ناتوانى يادگيرى در رياضى امرى

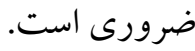
به بزخوهشخران بيشنهاد مى شود اين مداخله را، براى ساير

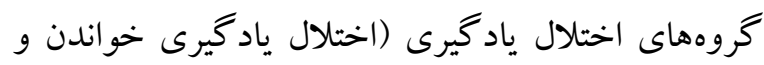
نوشتن) نيز اجرا نمايند. همجنين با توجه به سهولت استفاده از اين گونه برنامهها، جذابيت آنها براى كود كان و نيازمندى كودكان (كودكان عادى و كودكان با نيازهاى ويزه) به ارتقاى عملكردهاى شناختى، اين برنامهها در مدارس به عنوان بخشى از برنامهُ دانش آموزان در طى ساعات حضور كودكك در مدرسه به كودكان ارائه شود.

\section{سياسگز ارى}

بدينوسيله مراتب سباس خود از دانش آموزان و همجنين

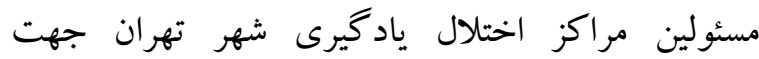

$$
\text { همكارى لازم را اعلام مى داريم. }
$$

\section{References}

Abedi A, Aghababaei S. Effectiveness of working memory training on academic performance of children

Abedi A, Malekpour M, Molavi H, Arizi SH, Amiri $\mathrm{SH}$. The Comparison of neuropsychological characteristics of children with learning
توجه به نتايج حاصل از اين يزوهش با استفاده از

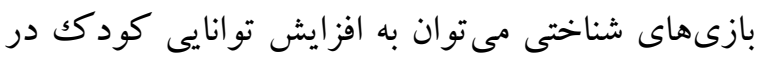
اين حوزه كمكك كرد. در واقع درمانهاى شناختى بر اين باور مبتنى هستند كه شناختها، احساسها و رفتارها، ماهيت تعاملى و متقابل دارند؛ بدين سبب رويكردهاى شناختى با نيازهاى دانش آموزان دجّار اختلالهاى ياد گيرى كه ويز گىهايى مانند درماندگى آموخته شده، نقص در خودنظمبخشى، آكاهى فراشناختى محدود و مشكلاتى در توجه و حافظه را نشان مىدهند، ساز گارى لرى زيادى دارند (هريس، ه191). يززوهشهايى كه نشانكر نقايص شناختى در بين افراد مبتلا به اختلالهاى ياد گيرى

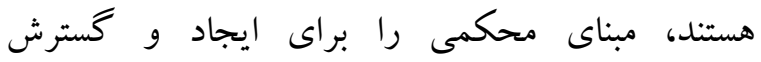
درمانهاى شناختى فراهم ساختهاند؛ زيرا اين رويكردها جندجانبه هستند و دستهُ وسيعى از راهبردها و فنون مناسب براى دانش آموزان مبتلا را با هم تلفيق مى كنند و به فعال ساختن دانش آموزان و سبردن كنترل و مسئوليت شخصى به آنها در ارائٔ راه حل مسائل تأكيد دارند

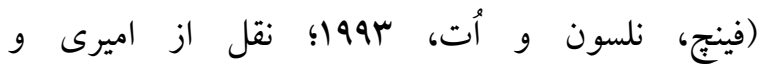

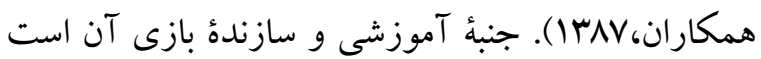
كه افراد به دنبال بيشرفت در بازى، سعى مى كنند طرز بازى كردن خود را اصلاح كنند (كاستر '، ا9V|؛ ترجمة رسولى و هاشمى، · •وس1). اكر جه مطالعاتى در زمينههاى درمان و افزايش عملكرد كاركردهاى اجرايى در كود كان داراى اختلال ياد كيرى رياضى صورت گرفته است، اما در زمينه بررسى اثربخشى انى بازىهاى شناختى بر افزايش عملكرد انعطافيذيرى

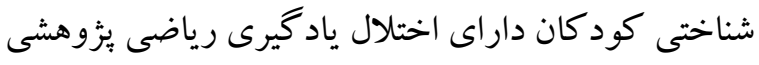

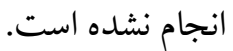


disabilities, neuropsychological/developmental and regular preschool. Q res areas except child. 2009; 8(1):1- 18. [Persian].

Alipor. A, Mahdavi Najmabadi. Z The comparison of central coherence between children with dyslexia, dysgraphia, dyscalculia and normal children. Joumal of Leaming Disabilities, Vol.3, No.3/112-118, Spring 2014. [In Persian]

Amani. M, Barahmand. U, Narimani. M. An examination of the effectiveness of neuropsychological and content-based training methods in the remediation of mathematics disorder. Joumal of Leaming Disabilities, (2012), Vol.1, No.2/7-21. [In Persian]

American psychiatric association. (2013). Diagnostic and statistical manual of mental disorders DSM-5.

Amiri. SH, Raisi Yazdi. M, Molavi. H. (2008) The Effect of Cognitive-Behavioral Therapy on the Mathematical Problem Solving for Students with Mental Disorders in Fifth Floor. Joumal Exceptional Children Research, 8, 1, 19-33. [n Persian]

Asgharinekah. M, Abedi. Z. The Effectiveness of Executive Functions based Play Therapy on improving Response Inhibition, planning and working memory in children with Attention Deficit Hyperactivity Disorder. Joumal of Cognitive Psychology, Vol. 2, No. 1, Spring 2014. [In Persian]

Blair, C., Zelazo, D \& Greenberg, M. (2005). The measurement of Executive Functions in Early childhood. J. Developmental neuropsychology, 28(2): 561-571.

Bottge BA, Heinrichs M, Chan SY. Serlin RC. (2001). Anchoring Adolescents

Bull, R., \& Scerif, G. (2001). Executive function as a predictor of children's mathematics ability: Inhibition, switching and working memory. Developmental Neuropsychology, 19, 273293.

Cappelletti, M, Lee, HL, Freeman, E, Price, C. (2010). The role of right and left parietal lobes in the conceptual processing of numbers. Cognitive Neuroscience. 22(2). 331-346.
Cohen Kadosh, R., Dowker, A., Heine, A., Kaufmann, L., and Kucian, K. (2013).Interventions for improving numerical abilities: present and future. Trends Neuroscience. Educ. 2, 85-93.

Daniel P, Halahan J, Kaufman LJ, Elizabeth M, Weiss M. Learning disorders (Foundations, characteristics, and effective teaching). Translated by: Alizadehh H, Hemmati Gh, RezaeiDehnavi S, shojai S. Tehran: Arasbaran issued.(1981). [Persian]

David. A. Sousa. Psychology of children with special needs. Translated by: Yarmohammadian A Kjbaf M. Tehran: Samt issued. (2001). [In Persian]

Gartland, D., \& Strosmender. R. (2007). Leaming disabilities and young children identification and intervention. Leaming Disability Quarterly, 30 (1), 63-72.

Ghamari Givi, H., Narimani, M., \& Mahmoodi, H. (2011). The effectiveness of cognitionpromoting software on excutive functions response in hibition and working memory of children with dyslexia and attention deficithyperactivity. Joumal mental health, 1 , 2,98-115. [In Persian]

Harris, K. R. (1988). Cognitive-behavior modification: Application with exceptional students. Effective Instructional Strategies for Exceptional Children (pp.216-242).

Hauser, Tobias. U, Rotzer, Stephanie, Grabner, Roland H, Mérillat, Susan, and Jäncke, Lutz. (2013) Enhancing performance in numerical magnitude processing and mental arithmetic using transcranial Direct Current Stimulation (tDCS). Human neuroscience 7: 244.

Janeh. M. Comparison of executive functions of reasoning, planning, organization and work memory in students with and without math disorders in elementary school. (Master's Thesis university of Allameh Tabatabai, 2008). [n Persian]

Korkman M, Pesonen, AE. (1994). A comparison of neuropsychological test profiles of children with attention deficit-hyperactivity disorder and/or learning disorder. Learning disability. (27). 383-392. 
Koster Roph. A Theory of Fun for Game Design. Translated by: Rasouli. T, Hashemi. A. Tehran: Game World issued. 2000. [In Persian]

Mirmahdi. R. The Effectiveness of Teaching Exercise Operations and Written Exercise Writing Technique on Improving the Performance of Teching, Reading and Writing Method for Writing Speech in Fourth Grade Students with Learning Disorders on E.R. (doctoral dissertation university of Allameh Tabatabai, 2007). [n Persain]

Moor, D.T. (2000). Eye exercises to increase attention and reduse impulsivity. Retrieved from the world wide web: http://www.altavista.com

Panksepp, J., Burgdorf, J., Cortney, T., \& Gordon, V. (2003). Modeling ADHD-type arousal with unilateral frontal cortex damage in rest and beneficial effect of play therapy. Joumal of brain and cognition, 52,97-105.

Reinecke, Mark A, Frank M. Dattilio, Freeman A. Cogncognitive therapy in children and adolescents. Translated by: Alaghbandanrad J, Farahi H. Tehran: Boghe issued. 2000. [In Persian]

Robinson, J. Z. (2003). Fifth grade students as emotional helpers with kindergarten children, using play therapy procedures and skills (doctoral dissertation university of north texas, 2001).

Rossi A, Arduini L, Danelluzzo E, Bustini M, Prosperini P, Stratta P. Cognitive function in euthymic bipolar patients, stabilized schizophrenic patients and healthy controls. J Psychiat Res. 2000; (34):333-339.

Rousselle L, Noel MP. (2007) Basic numerical skills in children with mathematics leaming disabilities: A comparison of symbolic vs non-symbolic number magnitude processing. Cognition, 102 (3): 361-395

Sadock B J, Sadock V A. Kaplan \& Sadock's synopsis of psychiatry. 10th ed. Philadelphia: Lippincott, Williams \& Wilkins; 2007.

Saheban, F., Amiri, F., Bagher Kajbaf, M., \& Abedi, M. (2010). The Efficacy of Short-Term Executive Functions Training on the Reduction of
Symptoms of Attention Deficit and Hyperactivity of Elementary Boy Students in Esfahan Metropolitan Area. Advances in Cognitive Science, 12, 1, 52-58. [In Persian]

Seyfenaraghi. M, Naderi. E. Specific Learning Disabilities. Tehran: Arasbaran issued. 2010. [In Persian]

Shekouhi Yekta M, Prand A. Leaming disabilities. 2nd ed. Tehran: Tabib Publication; 2010:81-9 [In persian].

Shekouhi Yekta M, Prand A. Psychology and Exceptional Children Education. Tehran: Teymoorzadeh Publication; ( 2010) [In persian].

Soltanikouhbanani. S, Alizadeh. H, Hashemi. J, Sarami.

GH, Soltanikouhbanani. S. (2013) Effectiveness of working memory computer assisted program on executive functions in students with mathematic disorder. Journal Behavioral Sciences Research, 3, 11, 208218. [In Persian]

Swanson, HL, Siegel, L. (2001). Elaborating on working memory and Learning disabilities. Issues in Education. 7 (1). 107-129.

Van der sluis, s. de jenge, p. F. \& Van der leij, A. (2004). Inhibition and shifting in children with learning deficits in arithmetic reading. $\mathrm{J}$ of Experimental Child Psychology 87: 239266.

Witt, M. (2011). School based working memory training: Preliminary finding of improvement in children's mathematical performance. Advance in Cognitive Psychology, 7(2), 7-15. 